\title{
EVALUATION OF ANSI Z535 SAFETY SIGN INSTALLATION
}

\author{
Mas Amaliyah ${ }^{1}$, Noeroel Widajati ${ }^{1}$ \\ ${ }^{1}$ Department of Occupational Safety and Health, Faculty of Public Health, Universitas Airlangga, Surabaya, \\ Indonesia
}

\section{ABSTRACT}

\begin{abstract}
A safety sign is a sign of equipment to provide protection for workers or visitors in the workplace. American National Standards Institute Z535 (ANSI Z535) is used as a basic guideline for installing safety signs in the workplace because it is more communicative by using global symbols to overcome language barriers. Occupational Safety Division of Manpower and Transmigration Departement, East Java Province (UPT Keselamatan Kerja Surabaya) is a workplace that has a risk of occupational accidents. The preliminary surveys in the area of the 3rd floor of the Division of Occupational Safety (UPT Keselamatan Kerja) Surabaya revealed that there were many sites with insufficient safety signboards. Many of the installed safety signs did not comply with ANZI Z535 standards. This study aimed to evaluate the installation of safety signs compared to the ANZI Z535 standard on the 3rd floor of UPT K2 Surabaya. This was an observational study examining the installation of safety signs. The data were obtained using the ANSI Z535 safety sign checklist. We found 2 out of 5 types of safety signs were in accordance with ANSI safety sign standards with a comparison percentage of more than 66\%, such as the notice sign (67.85\%) and safety condition sign (75\%). Three other types of safety signs were in the unfavorable category with a percentage of less than 66\%, such as danger sign (65.63\%), warning sign (50\%), and caution sign (46.88\%). Some sites required additional safety signs, such as warning signs (at distillation site), caution signs (oven, stairs), notice signs (cylinder storage, elevator, chemical warehouse), and safety condition signs (stair, eyewash).
\end{abstract}

Keywords: Safety signboard; ANSI Z535 standard; laboratory; public health

\section{ABSTRAK}

Safety sign adalah peralatan rambu/simbol yang berfungsi memberikan perlindungan pada tenaga kerja / pengunjung di tempat kerja. Standar ANSI Z535 digunakan sebagai pedoman dasar untuk penerapan safety sign di tempat kerja karena lebih komunikatif dengan menggunakan simbol secara global untuk hambatan bahasa. UPT K2 juga termasuk tempat kerja yang memiliki risiko terjadinya kecelakaan kerja. Berdasarkan hasil survei pendahuluan di area lantai 3 UPT K2 Surabaya banyak ditemukan tempat-tempat yang kurang mendapat perhatian terkait adanya safety signboard, dan banyak safety sign yang terpasang tidak sesuai dengan standar ANZI Z535, sehingga peneliti tertarik untuk melakukan penelitian evaluasi penerapan safety sign sesuai standar ANZI Z535. Metode penelitian yang digunakan observasional. Variabel yang diteliti yaitu aspek penerapan safety sign. Cara pengumpulan data diperoleh melalui checklist safety sign ANSI Z535. Berdasarkan hasil analisis diperoleh evaluasi kesesuaian penerapan safety sign di area lantai 3 UPT K2 Surabaya Dinas Tenaga Kerja dan Transmigrasi Jawa Timur yang dibandingkan dengan standar ANSI Z535 yaitu memiliki 3 dari 5 jenis safety sign sesuai dengan standar safety sign ANSI yaitu jenis notice sign dan safety condition sign, sedangkan 3 jenis safety sign lainnya termasuk dalam kategori kurang baik dengan prosentase perbandingan kurang dari 66\%. Masing-masing memperoleh skor kesesuaian yaitu danger sign (65,63\%), warning sign (50\%), caution sign (46,88\%), notice sign (67,85\%), safety condition sign (75\%). Berdasarkan hasil analisis risiko beberapa tempat membutuhkan safety sign tambahan yaitu warning sign (tempat destilasi), caution sign (oven, tangga), notice sign (penyimpanan tabung, lift, gudang kimia) dan safety condition sign (anak tangga, eye wash).

Kata Kunci: Tanda keselamatan; ANSI Z535; laboratorium; public health

Correspondence: Noeroel Widajati, Department of Occupational Safety and Health, Faculty of Public Health Universitas Airlangga Campus C Mulyorejo, Surabaya, East Java 60115. Email: noeroel.widajati@fkm.unair.ac.id.

pISSN:2355-8393 • eISSN: 2599-056x • doi: 10.20473/fmi.v57i3.25293

- Fol Med Indones. 2021;57:231-238 • Submitted 06 Feb 2021 • Received 29 Apr $2021 \bullet$ Accepted 18 Jun 2021

- Open access under CC-BY-NC-SA license • Available at https://e-journal.unair.ac.id/FMI/ 


\section{INTRODUCTION}

Work accidents are caused by two factors. First, the human factor, which includes work rules, worker's ability, work discipline, and physical and mental incompatibility. Second, mechanical and environmental factors, which include the location of the machine, not being equipped with protective equipment, not wearing protective equipment, and damaged work tools (Suma'mur 2014). Social Security National Insurance data shows that the number of work accidents in 20172018 has increased. In 2017, the number of work accidents reported was 123.041 cases. In the annual report of Social Security Provider (BPJS Ketenagakerjaan) in 2019 states that throughout 2018, this figure reached 173.105 cases with the nominal compensation paid reaching IDR1.2 trillion. As of September 2019, the total number of work accidents was 130,923 with a total claim of IDR1.09 trillion.

Working in a laboratory cannot be separated from potential hazards and risks of work accidents, such as the accident at the Qualitative Chemistry Laboratory at the Faculty of Pharmacy, Universitas Indonesia on March 16, 2015. Fourteen students were injured as a result of being hit by shards from a distillation flask explosion during practicum in the laboratory (Abidin \& Ramadhan 2019). A laboratory work accident also occurred to a chemist at the Forensic Laboratory Central Building due to sudden explosion of a 3-liter tank used to heat metal analyzers. This explosion resulted in the chemist experiencing burns to his hand, the glass door of the laboratory broke and white smoke coming out of the window with a burning smell (Suryanto 2011). The Education Bureau survey in 2011/2012 related to accidents in school laboratories showed that there were 348 cases of laboratory accidents reported. A total of 328 people were injured. Chemical laboratory ranks second as the place where work accidents occur most at school. The type of work accident in the laboratory are $39.1 \%$ had scratches, $37.6 \%$ minor burns, $8 \%$ eye accidents, and $7.2 \%$ were exposed to chemical spills (Dantjie et al 2016).

Laboratory accidents occur often not because of limited knowledge, but safety procedures. Workers relax their precautions while working, because workers feel that they are experts in doing their job (Kristiawan \& Abdullah 2020). The correct action by laboratory workers when working is classifying chemicals based on their properties, potential hazards, and precautionary information on the labels of each chemical. However, there are many misunderstandings or lack of proper knowledge to interpret chemical labeling (Latham et al 2013). Accidents in work environment are preventable. Efforts to prevent work accidents consist of various ways, one of which is by implementing a safety sign according to workplace standards (Basuki et al 2015).

The obligation to install safety signs in workplace is stated in Law Number 1 of 1970 concerning work safety, which is to post all required work safety signs and all other guidance materials in places that are easily seen and eligible according to the instructions of the supervisors or the occupational health experts. The Indonesia Government Regulation Number 50 of 2012 concerning the Implementation of Occupational Health and Safety Management System states that Occupational Safety and Health (OHS) signs must be installed according to technical standards and guidelines. Safety signs have various forms, including safety signs, illumination signals, acoustic signals, hand signals, verbal communication, and fire safety signs.

Safety signs are equipment in the form of signs and symbols that function to provide protection to workers and visitors in the workplace regarding health and safety (Suharto 2016; Wiratami \& Bhaskara 2018). American National Standards Institute Z535 (ANSI Z535) is an American standard that sets a system for presenting safety and accident prevention information to achieve performance excellence (Wachter \& Yorio 2014). The ANSI Z535 standard can be used as a basic guideline to implement safety signs in the workplace, because the standard is more effective in communicating security by using global symbols to overcome language barriers, with attracting content, and more substantially explaining hazards and ways of dealing with these hazards (Clarion 2013).

The Division of Occupational Safety (UPT Keselamatan Kerja) Surabaya is a technical implementation unit as a center for testing, inspecting, researching and training in the areas of company hygiene and work safety in the Province of East Java. This division was chosen as one of the best UPTs in Indonesia, because it has been accredited by the National Accreditation Committee (KAN). This division is also a workplace that has a risk of work accidents. A preliminary survey in the Division of Occupational Safety Surabaya area showed that many places lack safety signboards or do not comply with ANZI Z535 standards. An interview with laboratory workers revealed that when they distilled water for testing, they often forgot that the equipment used was hot, causing burns. This was because there was no sign that warn workers the hot condition of the equipment when it was operated and proved that the installation of a safety sign needs to be done, so that the workers become more careful. This study was conducted to determine whether the application of the safety sign was in accordance with the ANZI Z535 standard. 


\section{MATERIALS AND METHODS}

This study was an observational study conducted at the Division of Occupational Safety, Department of Manpower and Transmigration, Surabaya, East Java, Indonesia. The area chosen to be the research location was the 3rd floor. Data collection was carried out from August to October 2020. The object of this research was safety signs on the 3rd floor area of the office.

The variable being studied was the aspect of the installation of safety sign. Data were obtained through the ANSI Z535 safety sign checklist. Primary data were the result of observations, while secondary data were obtained from documents related to hazard identification, company's profile of the agency and other supporting documents. Data analysis was carried out by comparing the application of the safety sign in the field with the standards to obtain conformity category for its application with the following percentage, namely poor $(0-33.3 \%)$, insufficient $(33.4$ $-66.7 \%)$, and good $(66.8-100 \%)$.

\section{RESULTS}

The operational activities of the Division of Occupational Safety Surabaya were mostly carried out on the 3 rd floor. On the $3^{\text {rd }}$ floor, there was a laboratory area where laboratory analyst workers processed the results of sampling by PCU. This division had implemented several controls. However, administrative control efforts, such as implementing a safety sign, had not been implemented optimally. Field observation showed that many safety signs were inappropriate and many messages on safety signs could not be read clearly.

\section{Danger sign}

Table 1. Conformity of danger sign installation on the $3^{\text {rd }}$ floor

\begin{tabular}{lll}
\hline Location & Item Conformity & $\%$ \\
\hline $\begin{array}{l}\text { Flammable liquid sign in } \\
\text { storage room }\end{array}$ & 11 of 16 & $68.75 \%$ \\
$\begin{array}{l}\text { Corrosive substance sign in } \\
\text { storage room }\end{array}$ & 10 of 16 & $62.50 \%$ \\
\hline \multicolumn{2}{r}{ Total } & $65.63 \%$ \\
\hline
\end{tabular}

The danger sign installation was still not good. Two danger signs had a total sign conformity with the ANSI Z535 standard of $65.63 \%$ (insufficient). Two danger signs in chemical storage room, namely the flammable liquid sign and corrosive substance sign. After analyzing with ANSI Z535, they had suitability percentages of $68.75 \%$ and $62.50 \%$ respectively. The letter of description or message did not use black font, the effects of the type of hazard were not available, the countermeasures were not listed, and the material was not made of durable material.

\section{Warning sign}

Table 1 . Conformity of warning sign installation on the $3^{\text {rd }}$ floor

\begin{tabular}{lll}
\hline Location & Item Conformity & $\%$ \\
\hline $\begin{array}{l}\text { No smoking sign in the } \\
\text { middle room area }\end{array}$ & 7 out of 16 & $43.75 \%$ \\
$\begin{array}{l}\text { Restricted area sign on the } \\
\text { laboratory entrance door }\end{array}$ & 7 out of 16 & $43.75 \%$ \\
$\begin{array}{l}\text { Magnetic sign on the AAS } \\
\text { room door }\end{array}$ & 11 out of 16 & $68.75 \%$ \\
$\begin{array}{l}\text { PPE sign on the laboratory } \\
\text { entrance door }\end{array}$ & 7 out of 16 & $43.75 \%$ \\
\hline Total & & $50 \%$ \\
\hline
\end{tabular}

The installation of warning signs in some of these locations was not good with a $50 \%$ conformance. The four signs conformity to ANSI Z535 standards, it got 3 signs which obtained $43.75 \%$ for no smoking signs, restricted area signs and APD signs, and $68.75 \%$ for magnetic signs. There were no warning words on the installed sign, no information (source of danger, effect and handling method) or the message conveyed was not present, the writing on the sign was too small, so that it could not be read, and the sign was not made of durable material.

\section{Caution sign}

Table 3. Conformity of caution sign installation on the $3^{\text {rd }}$ floor

\begin{tabular}{|c|c|c|}
\hline Location & Item Conformity & $\%$ \\
\hline $\begin{array}{l}\text { Hot surface sign on } \\
\text { preparation table }\end{array}$ & 7 of 16 & $43.75 \%$ \\
\hline $\begin{array}{l}\text { Hot tools sign at the } \\
\text { laboratory oven hood }\end{array}$ & 8 of 16 & $50 \%$ \\
\hline & Total & $46.88 \%$ \\
\hline
\end{tabular}

The caution sign installation was analyzed with ANSI Z535, and got a total score $46.88 \%$. It indicated that the sign was poor category. The lack of caution sign was the word "caution" on each sign was not available, the type of hazard was not included, information on the effect of the hazard was not available, there was no prevention method, the font size was too small, and the sign was not made of durable material. The caution sign 
on the preparation table should be placed in an area not covered up by laboratory testing equipment.

\section{Notice sign}

Table 4. The conformity of the notice sign installation on the $3^{\text {rd }}$ floor

\begin{tabular}{lll}
\hline Location & Item Conformity & $\%$ \\
\hline Acid base cabinets & 10 of 14 & $71.43 \%$ \\
Sampling equipment washer & 8 of 14 & $57.14 \%$ \\
$\begin{array}{l}\text { Sample bottle color rule in } \\
\text { sample bottle storage cabinet }\end{array}$ & 10 of 14 & $71.43 \%$ \\
$\begin{array}{l}\text { Magnetic area sign in AAS room } \\
\text { Close sign in instrument storage }\end{array}$ & 10 of 14 & \\
$\begin{array}{l}\text { Dryer over for laboratory } \\
\text { equipments }\end{array}$ & 9 of 14 & $71.43 \%$ \\
& & $64.29 \%$ \\
\hline
\end{tabular}

The installation of notice signs on the 3rd floor of the Division of Occupational Safety Surabaya was considered good with a total score of sign conformity with ANSI standards reaching 67.85\%. Based on ANSI Z535 standard, the notice sign consisted of four signs at good category $(71,43 \%)$, but still had 2 signs with insufficient score $(<66.8 \%)$. It showed that sampling equipment sign and dryer equipment sign needed to improve for conform with ANZI Z535. However, nonconformity with the ANSI Z535 was still found. For example, the sign was not square, had no notice sign, the background color of the sign description was not white, there was no pictogram describing hazards, and the sign was not made of durable materials.

\section{Safety condition sign}

Table 5. The conformity of the installation of safety condition sign on the $3^{\text {rd }}$ floor

\begin{tabular}{lll}
\hline Location & Item conformity & $\%$ \\
\hline Exit sign at the laboratory & 8 of 10 & $80 \%$ \\
$\begin{array}{ll}\text { Firing Extinguishing } \\
\text { Equipment Sign }\end{array}$ & 7 of 10 & $70 \%$ \\
\hline \multicolumn{2}{l}{ Total } & $75 \%$ \\
\hline
\end{tabular}

The installation of safety condition sign at that location was regarded as in good category with a $75 \%$ conformity level. The remaining discrepancies were the color of the caption letters was black, which should have been white, there was no pictogram explaining the contents of the sign message, and the material was not durable. The safety condition sign was only made of HVS paper. Apart from observing the safety sign installed, we also identified risks. A sign that described the risk of occurrence in an area must be installed with the following results:

\section{Risk identification}

The risk identification resulted as in the following table.

Table 6. Risk identification of the $3^{\text {rd }}$ floor

\begin{tabular}{lll}
\hline Locations & Danger & Effect of the Dangers \\
\hline Distillation area & Contact with hot equipment & Burns to minor injuries \\
& Manual lifting and wrong lifting position & Complaints of MSDs to minor injuries \\
Oven are & Contact with hot equipment & Burns to minor injuries \\
Chemical substances storage area & Unlabelled chemical substances & Fall and injury \\
Stairs area & Sloping surface and prone to slippery & Injury \\
Gas cylinder storage area & Stuck and pinched by a gas cylinder & Falling elevator and accident \\
Freight Elevator area & Excessive load if not according to designation & Electrocution and injury \\
Panel room & Electricity and other networks & Not energy saving \\
Ablution site & Excessive use &
\end{tabular}


It was found that the average weight of deceased with this risk identification, the signs that must be installed were as follows:

Table 7. Addition of new signs according to the results of risk identification on the $3^{\text {rd }}$ floor

\begin{tabular}{|c|c|}
\hline Locations & Type of signs \\
\hline $\begin{array}{l}\text { Distillation area - water } \\
\text { heating area }\end{array}$ & $\begin{array}{l}\text { Warning sign - do not touch during } \\
\text { operation. }\end{array}$ \\
\hline $\begin{array}{l}\text { Distillation area }- \\
\text { distilled water container } \\
\text { area }\end{array}$ & Warning sign - heavy weight, use tools. \\
\hline $\begin{array}{l}\text { Oven area or equipment } \\
\text { drying area }\end{array}$ & $\begin{array}{l}\text { Caution sign - hot oven, wear heat } \\
\text { proof gloves. }\end{array}$ \\
\hline Stairs area & $\begin{array}{l}\text { Caution sign - sloping surface, use } \\
\text { handrail in this area. }\end{array}$ \\
\hline Gas cylinder storage area & $\begin{array}{l}\text { Notice sign - Keep the cylinders safe } \\
\text { and in an upright position. }\end{array}$ \\
\hline Freight elevator area & $\begin{array}{l}\text { Notice sign - Elevator only for } \\
\text { materials }\end{array}$ \\
\hline Electric panel room & $\begin{array}{l}\text { Notice sign - restricted area for } \\
\text { authorized personnel only. }\end{array}$ \\
\hline $\begin{array}{l}\text { Chemical substance } \\
\text { storage room }\end{array}$ & $\begin{array}{l}\text { Notice sign - all bottles should be } \\
\text { labeled (according to chemical } \\
\text { substances MSDS). }\end{array}$ \\
\hline Ablution site & Notice sign - Turn the tap off after use \\
\hline Stairs area & $\begin{array}{l}\text { Safety condition sign - Arrow } \\
\text { directions up and down the stairs }\end{array}$ \\
\hline Eyewash \& shower area & $\begin{array}{l}\text { Safety condition sign - Eyewash and } \\
\text { shower location sign }\end{array}$ \\
\hline
\end{tabular}

Some places require additional safety signs to reduce the level of risk in those places. Additional safety signs were recommended using the ANZI Z535 standard, because the language style used was easy to understand. Safety signs were needed to reduce the hazards in the place. In addition, safety signs also served to increase the level of alertness of workers during in the area.

\section{DISCUSSION}

\section{Conformity of danger sign}

Danger sign is a sign for a hazardous situation which can inevitably result in death or serious injury. This condition shows the most extreme situation (American National Standards Institute 2011). The installation of hazard signs on the 3rd floor area of UPT K2 was in the poor category $(65.63 \%)$, because there were no components, such as the word "DANGER", that there were no effects and means to deal with hazards; and the danger signs were made of materials that were not durable. According to ANSI Z535 in Clarion (2013), the word "DANGER" must be present and was in white color on a red background, there were sources of danger presented at the location, effects of sources of danger, and ways of dealing with them. Besides, captions must be black in color with active voice, include punctuation marks and use pictograms or images on a white background (Clarion 2013).

When the danger sign was not installed properly is from fire to explosion. Fire occurs when flammable chemicals (organic solvents and gases) come into contact with the heat source. The heat source can be open flame, hot metal, and embers or electric shocks. Fires can also cause other more powerful explosions; or can also produce other toxic materials (Harjanto et al 2011). The installation of a safety sign is that a safety sign must be clearly visible, placed at an appropriate distance, not blocked by objects, there must be sufficient lighting in the area, and be visible from various directions (Health and Safety Executive 2009).

\section{Conformity of warning sign}

Warning sign indicates a danger which, if not avoided, could result in serious injury or death (American National Standards Institute 2011). The conformity of the safety sign with the ANSI Z535 standard was in poor category $(50 \%)$, because there were several components that were not available in the safety signs, including the absence of the word "WARNING" on the signs, no information (source, effects, and how to overcome), the writing on the signs was too small, and the signs were not made of durable materials. Based on the results of interview with informants, the installed signs had not been made according to the ANZI Z535 standard due to limited costs and manpower for the process.

According to ANSI Z535 standard in Clarion (2013), the warning sign must include the word "WARNING" in black with an orange background column, containing a description of the source of the danger, the effect it causes, and how to deal with the hazard, and have a pictogram/picture to clarify the information. Messages should be written in black with a short active sentence and are accompanied by clear punctuation (Clarion 2013). The impact of the absence of a magnetic warning sign is damage to electronic goods and is dangerous for the use of a pacemaker, because electronic equipment or magnetic devices must not be close to other magnetic 
devices that are stronger, because the equipment will lose its stability (Jufriyah et al 2019).

The warning sign regarding the use of PPE before entering the laboratory area aims to remind workers during certain conditions to use PPE if technical safety controls (engineering control) and administrative controls cannot provide optimal safety protection (Solichin et al 2014). The warning signs found on the 3rd floor of UPT K2 were mostly made of HVS paper and affixed with double type adhesive. Both materials were chosen, because they were easy to come by, did not take a long time to process and the price was affordable, but for the resilience of the two materials were not durable, while according to ANSI Z535 materials used to make the sign of salvation in the room must be durable, such as acrylic sticker, aluminum or heat resistant stickers (Health and Safety Executive 2009).

\section{Conformity of caution sign}

Caution sign is a sign indicating a dangerous situation which, if not avoided, will result in minor or moderate injury (American National Standards Institute, 2011). The conformity of the caution sign with the ANSI Z535 standard was not good (46.88\%). All types of safety signs recommended by ANSI Z535, the caution sign had the lowest score, because the shape of this sign was mostly too small and placed in an arena that was often blocked and was not equipped with equipment. It also could not be seen, and many writings on signs were also lost, because the signs were installed on hot equipment, but sign materials were not heat resistant, so that many sign messages were not clearly visible.

ANSI standard Z535 (2011) states that a caution sign must show the word "CAUTION" in black on a yellow background accompanied by a pictogram (image). Captions and images are in a white background column. The notes should be in black in active voice and signs. The information contains the source of the hazard, the effects causes, and how to overcome it (American National Standards Institute 2011).

If the caution sign on the danger of hot surfaces was not installed, there could be work accidents in the form of burns to the skin, resulting in fluid loss due to excessive evaporation in first degree burn, fluid buildup in bullae in the second degree burns, and discharge from scabs in the third degree burn. The burn area of less than 20\% was still compensated by the balance of body fluids. However, if more than $20 \%$, there would be a risk of hypovolemic shock with signs, such as restlessness, pale, cold, weak and rapid pulse, as well as a decrease in blood pressure and urine production (Anggowarsito 2014).

The writing on the caution sign was found to be faded, because the materials used were not durable and lacked attention to care. Signs need to be cared for properly by replacing signs that are faded, damaged or worn out, changing safety signs that are poorly understood or often ignored, removing a number of safety signs, or no longer needed, and painting signs whose colors have faded (IAPA 2007).

\section{Confirmity of notice sign}

A notice sign serves to provide information that is deemed important, for example instructions or restrictions on workers or other individuals in the workplace that are not always related to hazards in the workplace, such as property damage notifications, and so on (American National Standards Institute 2011). Conformity with Z535 standard was good (69.05\%). These safety signs were in good category, because most of them had been well implemented compared to other types of safety signs, so that most of the notice sign safety signs in the division were in accordance with the ANZI Z535 standard.

ANSI Z535 regulates several aspects that must be fulfilled when making a notice sign, including the sign must be in square form with a column on a blue background, accompanied by a word "notice" in white and a white column, the information on instructions or prohibitions to perform certain actions, while working is clear and easy to understand in active voice and short black sentences with clear punctuation marks. Besides, the material used must also be durable, so that it can function optimally (American National Standards Institute 2011).

\section{Conformity of safety condition sign}

Safety condition sign provides instructions on appropriate safety measures, safety practices and where to find safety equipment. This sign is not associated with a specific color (American National Standards Institute 2007). On the 3rd floor of the division, the conformity safety condition sign with ANSI Z535 standard was categorized as good $(75 \%)$.

The discrepancies found were on the colors used in the description that were not in accordance with the standard, even though the dominant colors were appropriate (green) for safety equipment and red for firefighting equipment (Health and Safety Executive 2009). The location mark of the fire extinguisher did not have a pictogram and was made of non-durable 
material, so that many signs were detached. The location sign of the FE is highly important for fire management for it can be easily accessed (Kurniawan et al 2014).

\section{Addition of a new safety sign according to risk assessment}

The risk assessment on the 3rd floor of the division found a number of potential hazards. Potential hazards from various activities in the production process depend on the materials, equipment used, and the type of activity (Purohit et al 2018). The high risks found were chemical hazards in the laboratory area and medium risks were physical, chemical and ergonomic hazards in storage and office area. The risk control strategy is to reduce the likelihood of an event occurring, reduce the consequences/exposure received, and control risks (Calatayud \& Ketterer 2016).

The Decree of the Minister of Manpower Number 187 of 1999 concerning the control of hazardous chemicals stipulates that employer or those who use, store, produce and transport chemicals in a workplace are required to control hazardous chemicals to prevent occupational accidents and occupational diseases. According to ANSI standards, the installation of a safety sign can be used to reduce potential hazards. The application of a safety sign is a communication hazard for workers in accordance with OSHA which states that hazard communication is a way of indicating that an object or area contains a certain type of hazard. The examples of hazard communication are training activities, induction, safety talk or tool box meetings, OHS signs/signs, symbols of hazard on product packaging, and Material Safety Data Sheet (Occupational Safety and Health Administration 2016).

Additional safety signs that should be installed on the 3rd floor of the division were warning sign for distillation area, caution sign for oven and ladder areas, notice sign in chemical storage area, gas cylinder storage, freight elevator area, panel room, additional water saving notification sign, additional safety sign on the emergency shower, eyewash area markers, signs for going up and down the stairs. The sign on the stairs should indicate the floor level, and the top and bottom ends of the staircase are protected. According to Ministry of Public Works regulation Number No.26/PRT/M/2008 declares that when a contrasting new sign is used on the stairs; it is necessary to use material that blends with the entire width of the edge of the stair. Signs are placed on the entire width of the edge of each stair.

\section{CONCLUSION}

The evaluation of the conformity of safety sign installation in the 3rd floor of the Division of Occupational Safety Surabaya, Manpower and Transmigration Office, East Java, was performed by comparing with ANSI Z535 standard. Three of five types of safety sign were in accordance with the ANSI safety sign standards, such as the notice signs and safety condition signs. The other three types of safety sign were categorized as not in conformity with a percentage ratio of less than $66 \%$.

The majority of safety sign incompatibilities with the ANSI Z535 standards were in the aspects of safety sign header, background color being used, message description, and non-durable materials used. In addition, risk identification indicated the need for additional safety signs, including warning signs at distillation sites, caution signs on ovens or dryers, staircase areas, notice signs in gas cylinder storage areas, freight elevator, electrical rooms, chemical storage sites, ablution sites, safety condition sign on the stairs, and eye wash emergency area.

The recommendations that can be made by the Work Safety Unit according to the results of the analysis of the suitability of safety signs with ANSI Z535, pay more attention to the application of safety signs according to the needs and types of hazards existing in the place. The results of this study could be used as a basis for submitting the procurement of safety signs that must be in accordance ANSI Z535 standard. The application of safety signs could be used as a long-term investment for companies to improve occupational safety and health.

\section{REFERENCES}

Abidin AU, Ramadhan I (2019). Penerapan job safety analysis, pengetahuan keselamatan dan kesehatan kerja terhadap kejadian kecelakaan kerja di laboratorium perguruan tinggi. Jurnal Berkala Kesehatan 5, 76-80.

Anggowarsito JL (2014). Luka bakar sudut pandang dermatologi. Jurnal Widya Medika Surabaya 2, 113120.

Basuki M, Susanto RB, Herianto HP, et al (2015). Analisis Risiko Kegiatan Bongkar Muat Sebagai Komponen Dwelling Time Di Pelabuhan. 5, 511-518.

Calatayud A, Ketterer JA (2016). Integrated value chain risk management. United States, Inter-American Development Bank.

Clarion A (2013). New OSHA/ANSI safety sign systems for today's workplaces. Amerika Serikat, 
Clarion Safety Systems. Available from https://www.ishn.com/ext/resources/Resources/whitepapers/Clarion_ISHN_Whitepaper.pdf. Accessed November 5, 2020.

Dantjie PR, Widjasena B, Suroto S (2016). Perbedaan pengetahuan, sikap dan praktik keselamatan dan kesehatan kerja laboratorium antara mahasiswa program studi D3 dan S1 pada institusi pendidikan di Semarang. Jurnal Kesehatan Masyarakat 4, 97-107.

Harjanto NT, Suliyanto S, Ismojowati ES (2011). Manajemen bahan kimia berbahaya dan beracun sebagai upaya keselamatan dan kesehatan kerja serta perlindungan lingkungan. PIN Pengelolaan Instalasi Nuklir IV, 54-67.

Health and Safety Executive (2009). Safety signs and labels. Health and Safety Executive 94(2), 98.

IAPA (2007). Safety signs and colour at work. Industrial Accident Prevention Association. http://www.iapa.ca. Accessed November 5, 2020.

Jufriyah J, Mar'ah I, Isharyudono K (2019). Pemeliharaan dan penyimpanan peralatan laboratorium kimia. Jurnal Pengelolaan Laboratorium Pendidikan 1, 26-32.

Kristiawan R, Abdullah R (2020). Faktor penyebab terjadinya kecelakaan kerja pada area penambangan batu kapur unit alat berat PT. Semen Padang. Jurnal Bina Tambang 5, 11-21.

Kurniawan B, Ekawati E, Firdani L (2014). Analisis penerapan alat pemadam api ringan (Apar) di PT. X Pekalongan. Jurnal Kesehatan Masyarakat 2, 300-308.

Latham G, Long T, Devitt P (2013). Children's misunderstandings of hazard warning signs in the new globally harmonized system for classification and labeling. Issues Compr Pediatr Nurs 36, 262-78.

Purohit DP, Siddiqui NA, Nandan A, et al (2018). Hazard identification and risk assessment in construction industry. International Journal of Applied Engineering Research 13, 7639-7667.

Solichin S, Endarto FEW, Ariwinanti D (2014). Penerapan personal protective equipment (alat pelindung diri) pada laboratorium pengelasan. Jurnal Teknik Mesin 22, 89-103.

Suharto S (2016). Studi tentang keamanan dan keselamatan pengunjung hubungannya dengan citra destinasi (studi kasus Gembira Loka Zoo). Jurnal Media Wisata 14, 287-304.

Suma'mur PK (2014). Higiene Perusahaan dan Kesehatan Kerja (HIPERKES). Jakarta, Gunung Agung.

Suryanto S (2011). Ledakan di mabes polri kecelakaan kerja powered satu. https://www.antaranews.com/berita/244709/ledakandi-mabes-polri-kecelakaan-kerja\#mobile-nav.

Accessed December 17, 2020.

Wachter JK, Yorio PL (2014). A system of safety management practices and worker engagement for reducing and preventing accidents: An empirical and theoretical investigation. Accident Analysis \& Prevention 68, 117-130.

Wiratami R, Bhaskara GI (2018). Penerapan Keselamatan dan Kesehatan Kerja (K3) pada Atraksi Adventure Tourismdi Kawasan Air Terjun AlingAling Sambangan. Jurnal Destinasi Pariwisata 5, 287293. 